\title{
O PROCESSO ANTROPOFÁGICO NO “AUTO DE SÃO LOURENÇO” DE JOSÉ DE ANCHIETA
}

\section{THE ANTHROPOPHAGIC PROCESS IN “AUTO DE SÃO LOURENÇO” BY JOSÉ DE ANCHIETA}

\author{
Samuel Anderson de Oliveira Lima ${ }^{1}$
}

\begin{abstract}
RESUMO
A literatura dos primeiros anos de nossa formação, ou seja, do período em que estavam aportados em nossas terras os jesuítas, homens cujo labor era especialmente a educação do ameríndio, foi estudada por alguns teóricos com certo ranço romântico. Isso quer dizer que o olhar para as obras produzidas naquele período minimizou a importância dessa literatura, tratando-a apenas como uma "cópia" da produção portuguesa, sem tanto valor para nossa formação. Os jesuítas que vieram à América tinham como uma de suas principais atribuições a educação religiosa do povo indígena e uma de suas ferramentas mais usadas foi a dramaturgia. Estavam em voga, na Península Ibérica, os Autos de Gil Vicente e é certo que José de Anchieta teve contato com esse estilo quando estudou em Coimbra. Com o objetivo de retificar esse pensamento preconceituoso para com a obra anchietana, neste artigo, propomos uma leitura barroco-antropofágica da peça teatral "Auto de São Lourenço", que foi representada em 1587 onde hoje se encontra Niterói. Com a análise desse corpus, mostraremos o processo de devoração cultural empreendido pelo jesuíta e realizado através da amalgamação linguística. Nessa peça, há a mistura de várias línguas, portanto, de várias culturas. Ou seja, um texto permeado de culturas, como um amálgama, é símile do processo barrocoantropofágico estudado pelo modernista Oswald de Andrade. Este trabalho é resultado de uma pesquisa desenvolvida no âmbito da Iniciação Científica da UFRN.
\end{abstract}

PALAVRAS-CHAVE: José de Anchieta, Barroco, Antropofagia, Teatro.

\begin{abstract}
Theoretical researchers who supported the use of a romantic approach in literary works analyzed the literature that was addressed in the early years of the formation of Brazil - period that the Jesuits landed on Brazilian territory to educate the Amerindians. A critical look at the literary works developed during that period made this literature less important, since it was treated only as a copy of Portuguese works and little meaningful for Brazilian formation. The Jesuits who came to America had as one of their main attributions the religious education of the indigenous people and so dramaturgy was one of the most used tools. At that time, the works of Gil Vicente known as "Autos" were popular in the Iberian Peninsula. Thus, it is certain that José de Anchieta had contact with this style during his studies in Coimbra. This article thereby aims to rectify this prejudiced perspective concerning the works of José de Anchieta. For this purpose, it was suggested a baroque and anthropophagic reading of "Auto de São Lourenço" - a theatrical production that was developed in 1587 in the place currently known as Niteroi, RJ. Through the analysis of this play, this study demonstrates the process of cultural imposition conducted by the Jesuits and accomplished using linguistic amalgamation. In conclusion, this play mixes many languages and cultures. Thus, a text permeated by cultures as an amalgam is comparable to the baroque and anthropophagic process studied by the modernist Oswald de Andrade. This work is the result of research carried out under the UFRN Scientific Initiation.
\end{abstract}

KEYWORDS: José de Anchieta, Baroque, Anthropophagy, Theater.

1 Doutor em Literatura Comparada pela Universidade Federal do Rio Grande do Norte, Professor do Programa de Pós-graduação em Estudos da Linguagem - PPgEL/UFRN e Coordenador do Grupo de Pesquisa Ponte Literária Hispano-brasileira. E-mail: sanderlima25@yahoo.com.br. 


\section{INTRODUÇÃO}

José de Anchieta nasceu em 19 de março de 1534, Tenerife, Ilhas Canárias. Filho de um pai basco, Juan Jópez de Anchieta, e de uma mãe canária, Doña Mência Días de Clavijo y Llerena, o menino recebeu sua primeira educação em casa, como era costume ocorrer com os filhos de famílias abastadas. Só depois é que frequentou a escola dos dominicanos, tendo destaque no estudo da gramática latina. Aos 14 anos de idade, em 1548, Anchieta deixa seu lar em companhia de seu irmão mais velho, Pedro Nunes, e segue para Coimbra, onde se matricula no Colégio das $\operatorname{Artes}^{2}$, o orgulho do rei D. João III. Anchieta teria ali a mais pura educação do Renascimento, tanto que hoje é considerado um dos grandes humanistas daquele século (Cf. CAXA; RODRIGUES, 1988).

No contexto histórico em que se encontra o poeta, está o período em que a Igreja Católica perdia adeptos para a Reforma Protestante (Martinho Lutero publicou suas 95 teses no dia 31 de outubro de 1517). Dessa maneira, com o objetivo de "salvar" sua instituição, a Igreja, por meio da Reforma Católica (idealizada durante o Concílio de Trento), criou a ordem chamada "Companhia de Jesus"3, tendo como líder o espanhol Inácio de Loyola. Essa ordem religiosa foi a principal personagem da expansão do catolicismo no mundo e, para essa empreitada, precisava de jovens mancebos que pudessem desbravar as terras onde estavam as almas a serem "resgatadas". Os jesuítas tiveram muito destaque no cumprimento das metas da Reforma Católica. O escritor Riolando Azzi (1987, p. 39), no livro A cristandade colonial, comenta o seguinte sobre os objetivos da Companhia de Jesus:

De fato, a Companhia de Jesus é fundada exatamente na época em que se afirmava o movimento da reforma tridentina, visando, seja o fortalecimento da moral na Igreja contra a influência da mentalidade renascentista, seja o restabelecimento do espírito de autoridade abalado pelo movimento protestante.

José de Anchieta, então, aceitou o chamado da ordem para ser um dos agentes de resgate e difusão da fé católica, tornando-se jesuíta no dia $1^{\circ}$ de maio de 1551 . Riolando Azzi (1987, p. 39) confirma que os jesuítas, por seu vigor e dedicação ao intelecto, contribuíram para a execução dos objetivos contrarreformistas da Igreja Católica, não só pelas questões da força e do espírito, mas também pela política: "para a afirmação da contrarreforma, concorreu também o fato de que os jesuítas, além do domínio na área cultural, exerciam grande influência política junto à Coroa”. Jean Lacouture (1994, p. 31, grifos do autor), no livro Os jesuitas, fala dos dois caminhos pelos quais deveriam seguir os inacianos e indica o aspecto da antítese barroca presente na literatura dessa época que estava na idealização da fundação da Companhia de Jesus e nela permaneceu desde então: "quem não veria aqui uma chave para o progresso do futuro do fundador da Companhia, posto que o momento decisivo é apenas de 'êxtase espiritual' mas também de 'entendimento intelectual' e que o profano se une ao sagrado?”. Algumas páginas depois, o historiador faz um destaque sobre o papel dos jesuítas entre os indígenas, que acabavam sendo conquistados pelos artifícios daqueles: "os jesuítas ganharam grande parte de seu prestígio fornecendo arpões para a pesca, anzóis, relhas de arado. Nenhum outro presente era mais apreciado por seus neófitos" (LACOUTURE, 1994, p. 432). Isso quer dizer que a "empresa" criada por Inácio de Loyola cumpriu com esmero todas as prerrogativas instituídas pela Igreja Católica para reaver seu poder,

\footnotetext{
2 O Real Colégio das Artes e Humanidades de Coimbra foi idealizado pelo rei D. João III ainda no ano de 1542. Foi fundado alguns anos depois, em 1548, e tinha como objetivo inicial preparar os alunos para o ensino universitário. $\mathrm{O}$ corpo docente era composto por humanistas, que buscavam tornar os estudantes fluentes nas línguas clássicas, dando especial atenção para a língua latina. Em 1555, sua administração passa para as mãos da Companhia de Jesus. (Cf. BRANDÃO, Mário. O Colégio das Artes. Coimbra: Imprensa da Universidade, 1924).

${ }^{3}$ A Companhia de Jesus foi idealizada por sete jovens estudantes em Paris, no ano de 1534. Três deles, tiveram destaque na criação da Companhia, Inácio de Loyola, basco, Francisco Xavier, navarro, e Simão Rodrigues, português. Só em 1540, por meio da bula Regimini militantis Ecclesiae, o papa Paulo III reconheceu oficialmente a Ordem.
} 
principalmente com a possibilidade de crescer o número de adeptos com a "descoberta" da América ${ }^{4}$.

Devido a uma enfermidade óssea, Anchieta viaja para o Brasil a fim de que os ares do Novo Mundo reabilitassem sua saúde. Sendo assim, no dia 08 de maio de 1553, viaja na caravana do segundo Governador-geral, Duarte da Costa, e aporta em terras brasileiras no dia 13 de julho do mesmo ano. Os biógrafos Caxa e Rodrigues (1988, p. 16) fazem o seguinte comentário sobre a indicação médica para Anchieta viajar ao Brasil:

\begin{abstract}
Não tendo já que fazer com ele os médicos, tendo novas os padres da terra do Brasil ser muito sadia, determinaram também com parecer dos médicos que fosse enviado a ela, e que poderia ser que com o novo céu, novos ares e novos mantimentos houvesse nele e em sua disposição alguma mudança.
\end{abstract}

Anchieta não retornaria ao seu país. Viveria todos os próximos quarenta e quatro anos em prol da evangelização do ameríndio. Ademais, foi também uma figura muito importante na fundação das principais cidades do Brasil Colônia, como São Paulo e Rio de Janeiro.

Com relação à educação, certamente Anchieta teve contato ainda nas Ilhas Canárias com festas populares que foram fontes de inspiração para a produção de seu teatro. Paulo Hernandes (2008, p. 16) afirma que "ali, o menino deve ter entrado em contato com festas populares com um certo tipo de teatro, com pantomimas e fantoches de feira, com aquele mundo do riso medieval que Mikhail Bakhtin tão bem descreve em seus estudos sobre François Rabelais". Além disso, dentre todos os jesuítas que vieram para o Brasil, Anchieta foi quem primeiro dominou de forma mais eficaz o idioma dos índios: "Anchieta estudou e dominou esta 'língua geral”" (HORNAERT et al., 2008, p. 121).

A vinda de Anchieta ao Brasil, como considera seus biógrafos, representou ao poeta duas coisas importantes: sua saúde reabilitada e a catequização dos indígenas. Os jesuítas tinham como uma de suas principais atribuições ganhar/trazer fiéis para a Igreja Católica, mas no caso dos indígenas, nas terras colonizadas, o processo era antes de catequização, já que, como se sabe, na visão do colonizador o índio não tinha alma, precisava ser guiado para o céu (VASCONCELOS, 1943). Então, nosso poeta saiu do Tejo em Lisboa com essa finalidade, mas, no Brasil, foi e fez diferente. Nos parece que o jesuíta José de Anchieta encontrou a alma indígena/brasileira e buscou outros mecanismos para ensinar-lhe sua fé. Através da literatura, consegue ir mais além da catequese, visto que tinha consciência da arte, era um poeta consciente. Anchieta endossa a liturgia, ou seja, percebemos em seus textos o elemento religioso católico, no entanto, ele veste o santo católico de índio, quando mescla as duas culturas e cria apenas uma. Europa e América, branco e índio, colonizador e colonizado são um na tessitura de seus textos, é um processo de transculturação que se instala. A fronteira entre o popular e o religioso é mínima.

Para dar ênfase a essa ideia, é importante comentar que José de Anchieta escreveu em quatro línguas: português, latim, guarani e espanhol, informação que nos leva a refletir sobre o aspecto antropofágico de sua obra, principalmente quando mistura as línguas em um só texto, como vamos ver a seguir. Sobre esse aspecto, nos comentam Caxa e Rodrigues (1988, p. 78-79):

\begin{abstract}
Outras muitas obras compôs em diversos tempos, porque tinha para isso muita graça e facilidade, em todas as quatro línguas que sabia, latina, portuguesa, espanhola e brasílica. Mudava cantigas profanas ao divino, e fazia outras novas, à honra de Deus e dos santos, que se cantavam nas Igrejas e pelas ruas e praças, todas mui devotas com que a gente se edificava, e movia ao temor e amor de Deus.
\end{abstract}

Vale comentar ainda o fato de Anchieta verter cantigas ditas profanas em cânticos sagrados. Ele aprendia a forma, a sonoridade, a letra, a musicalidade dos cantos indígenas e a estes inseria o

\footnotetext{
${ }_{4}^{4}$ É preciso considerar que os dois países mais importantes na época das navegações eram Espanha e Portugal e ambos tinham o catolicismo como religião oficial.
} 
elemento religioso/católico, formando, nesse sentido, um amálgama cultural, fruto da devoração antropofágica. Um exemplo disso ocorre no primeiro ato da peça “Auto de São Lourenço", objeto deste artigo, em que Anchieta verteu a canção profana "El ciego amor me prendió" ao divino em "El buen Jesus me prendió" (Cf. CARDOSO, 1977, p. 70).

A questão do trânsito de várias línguas no Brasil colonial precisa ser levada em consideração também porque não havia ainda uma língua oficial. Muitos pesquisadores afirmam que Anchieta não é um poeta brasileiro porque não escreveu exclusivamente em língua portuguesa, porém, como afirma Azevedo Filho (1966, p. 12) "Anchieta é um exemplo de como a língua portuguesa naquele tempo não estava ainda fixada na preferência dos escritores, o que demonstra que a literatura já era brasileira, embora não escrita em língua portuguesa". Ainda sobre esse assunto, o crítico conclui:

Havia coisas e sentimentos, ideias e episódios, que se misturavam na mente dos homens - colonos, catequistas e indígenas, - que não obrigavam a expressão portuguesa, mas que procuravam indiferentemente o espanhol, o tupi ou o latim, tanto quanto o português. Só com o tempo e a mão forte da colonização é que o português se foi impondo. (AZEVEDO FILHO, 1966, p. 12)

Nesse sentido, não era estranho ter essa efervescência de línguas nas terras brasileiras na época colonial. $\mathrm{Na}$ verdade, só corrobora com aquilo que estamos chamando de estado antropofágico.

\section{A Antropofagia e sua conceituação}

Neste artigo, vamos trabalhar com a visão teórica de Oswald de Andrade sobre a antropofagia. É interessante destacar aqui que não está posto nos escritos desse autor modernista que José de Anchieta é um antropófago, mas, por meio de nossas pesquisas sobre o tema, estamos seguros de que é possível afirmar que a obra teatral do jesuíta traz ressonâncias antropofágicas, antecipando, de algum modo, o sentido dado por Oswald de Andrade à antropofagia no início do século XX.

Que seria então a antropofagia oswaldiana? É a festa da devoração, que transforma a palavra patriarcal em um sintagma destituído de seu poder inicial criando outro diferente. Essa devoração antropofágica está estabelecida pelo universo do barroco, já que com seu transplante para a América houve uma mescla na cultura e na linguagem (LEZAMA LIMA, 2005). O que temos hoje é fruto desse processo de amalgamação.

Para nossa pesquisa, o que mais interessa saber é sobre a devoração linguístico-cultural. José de Anchieta "devorava" as línguas. É um verdadeiro canibal da palavra. Em sua biografia, sabemos que desde criança começou a estudar as línguas clássicas de sua época e quando chegou ao Brasil é quem primeiro aprende a língua do indígena, inclusive produzindo uma gramática ${ }^{5}$ (outros jesuítas fizeram a mesma coisa nos países hispano-americanos). Lúcia Helena (1981, p. 22), falando sobre o poeta Gregório de Matos, confirma nossa hipótese de que a devoração linguística é um processo antropofágico: "através de um texto crítico e estreitamente vinculado à realidade brasileira, o discurso literário de Gregório procede à devoração da palavra que representava, a nível estético, o estatuto do poder do colonizador". Embora a citação da pesquisadora seja direcionada especificamente à poética de Gregório de Matos, ela coaduna perfeitamente com a produção de José de Anchieta, pois ambos pertencem aos primeiros processos de produção literária no Brasil e ambos se utilizam do mesmo mecanismo antropofágico que é a devoração da palavra. Nesse sentido, Anchieta, podemos dizer assim, inaugura a literatura brasileira sob o aspecto da antropofagia oswaldiana no sentido que estamos discutindo aqui, com a devoração cultural e linguística dos ameríndios. Não há, é importante frisar, "destruição" da cultura indígena; o que há,

${ }^{5}$ Anchieta escreveu e publicou a Arte de Gramática da língua mais usada na costa do Brasil em 1595. 
no entanto, é uma mescla, um amálgama. O texto anchietano não é nem indígena nem europeu, é um produto dos dois.

Anchieta assimila a cultura do indígena, sua língua, suas canções, sua comida, sua fé, seus desejos e os utiliza para compor seus textos catequéticos, poemas ou dramas. Em seus textos, está presente de maneira expressiva o índio, mas este surge agregado à cultura do colonizador. Vale considerar também que não há aqui uma intenção antropofágica, já que na época não havia uma discussão sobre essa teoria, não era intencional, mas, ao produzir uma obra literária mesclando as culturas como se fossem uma só coisa, já é característico do pensamento antropofágico teorizado por Oswald de Andrade (1978).

O objetivo da antropofagia, entre outras coisas, segundo Bitarães Netto (2004, p. 63) é "resgatar os valores nacionais para divulgá-los em todo o mundo, fazendo com que o europeu aceitasse a cultura estrangeira não somente por uma perspectiva excêntrica, mas pelos critérios da diferença e da autenticidade". Anchieta não teve essa preocupação em valorizar o nacional, pois não havia nação, ainda estava em formação, mas o fato de conhecer profundamente a cultura autóctone, ou seja, devorá-la, e produzir textos com as duas culturas, nos leva a pensar no ideal antropofágico, isso porque estamos de acordo com o pensamento de que a obra de José de Anchieta contribui para a formação da identidade/literatura brasileira. Mário Faustino (2003, p. 44) nos ajuda nesse reconhecimento: "[...] mas esse missionário é, sem dúvida, e de longe, o primeiro poeta dentre os muitos, jesuítas ou não, que, até Gregório de Matos, escreveu no Brasil e sobre o Brasil".

No Manifesto Antropófago, num de seus aforisma, está dito que "só me interessa o que não é meu" (ANDRADE, 1978, p. 13), ou seja, me interessa o outro, o que é do outro, não o que é meu. Por isso, a palavra "devoração" é chave para pensar a antropofagia. O rito canibal tem este objetivo: devorar o outro, para obter sua força e seu valor, acumulando energia ao longo de sua existência. Uma pesquisadora brasileira nos diz algo bastante importante sobre o sentido da antropofagia e que nos ajuda a estudar a obra teatral de José de Anchieta: "praticar a antropofagia cultural é digerir simbolicamente a tradição cultural para poder ser capaz de ultrapassar o modelo que ela impõe e criar, a partir de uma unidade criativa e dessacralizadora, um modelo próprio" (GELADO, 2006, p. 32).

\section{Um teatro antropofágico}

A antropofagia é uma teoria basilar para o Barroco, não é possível pensar um sem o outro. Para Lezama Lima (2005), por exemplo, o Barroco possui uma tensão, ou seja, provoca um choque com a cultura institucionalizada; rompe os fragmentos e os unifica; rompe os traços instaurados pelo historicismo e os une, formando um novo. São as partes do cristal que se unem. São as ruínas do Velho Mundo criando o Novo. O Barroco representa aquisições de linguagem, linguagem crioula, que traduz essa mescla cultural que temos comentado aqui.

A obra de Anchieta está marcada pelas volutas do Barroco, tanto pelo fato histórico, uma vez que está inscrito no Seiscentos, como pela própria obra, pois traduz todo o conceito da teoria barroca. O Barroco é o estilo da dobra ${ }^{6}$ (DELEUZE, 2000), da antítese, do labirinto, da circularidade, do festim ${ }^{7}$ (SARDUY, 1988), da antropofagia, e isso está presente em Anchieta, talvez não tão explicitamente como em outros autores barrocos como Gregório de Matos, mas se estudado com um olhar filtrado, é possível encontrar esses elementos.

Uma informação importante que precisa ser comentada é que Anchieta sabendo muitas línguas, compõe suas peças teatrais mesclando-as. Mas a maioria dos textos está escrita em língua

\footnotetext{
${ }^{6} \mathrm{O}$ sentido da dobra deleuzeana aplicada ao barroco é o de que esse estilo é cíclico, é como uma voluta que forma um espiral, que vai do século XVI ao XXI, que circula pelas eras. É um movimento artístico que, como os fractais, se retorce replicando sua imagem infinitas vezes.

7 O festim barroco se relaciona ao movimento da festa, do banquete, da abundância, do exagero, do luxo, tudo relacionado à extravagância artificiosa da linguagem barroca.
} 
espanhola, que era sua língua materna. Por sua facilidade em aprender línguas, foi um dos primeiros a aprender a língua indígena, como observa Caxa e Rodrigues (1988, p. 18): "E tanto de raiz a aprendeu que não somente chegou a entendê-la e falá-la com toda a perfeição, e compor nela e trasladar as coisas necessárias para a doutrina e catecismos". Em seu teatro polilíngue, o dramaturgo constrói cenas onde os personagens falam cada um em línguas diferentes e, às vezes, um mesmo personagem fala várias línguas, conjugando no que estamos chamando de mestiçagem linguística.

O teatro de Anchieta é pedagógico, é uma verdadeira aula de catequese. Era concebido como parte de uma grande festa, religiosa, mas com partes francamente profanas e divertidas. Mas o texto do nosso jesuíta estava "impregnado pela vertente pessimista do cristianismo - a do pecado original" (PRADO, 1993, p. 22). Hernandes (2008, p. 23), por sua vez, afirma que Anchieta "criou um teatro evidentemente pedagógico, no sentido, porém, em que também eram pedagógicos os autos religiosos e as moralidades medievais". Além disso, é importante refletir sobre o fato de que Anchieta era um humanista e trouxe na bagagem todo um repertório de fonte medieval, que contribuiu para produção de sua obra: "Os jesuítas, em particular José de Anchieta, trouxeram para o Brasil a fonte medieval da poesia de língua portuguesa [...], foram os primeiros a tentar o aproveitamento poético da língua indígena" (FAUSTINO, 2003, p. 44). Por essa razão, a obra anchietana está em transição para o Barroco, porque ela tem influência do mundo medieval, conforme nos assegura o prof. Leodegário Amarante de Azevedo Filho (1966, p. 13): “[...] não há, na obra literária de Anchieta, seja qual for o gênero considerado, nenhuma influência do Renascimento. Ao contrário, toda ela se inspira no mundo medieval, em transição para o Barroco, em virtude da filiação do jesuíta aos ideais estéticos da Contrarreforma". E acrescenta o crítico: "[...] a Literatura Brasileira encontra as suas raízes mais profundas na Idade Média, iniciando-se com o Pré-barroco jesuítico" (AZEVEDO FILHO, 1966, p. 13). Para Décio de Almeida Prado (1993, p.15), por seu turno, o teatro anchietano coincide com a formação da nossa identidade: "Se entendermos espetáculos amadores isolados, de fins religiosos ou comemorativos, o seu aparecimento coincide com a formação da própria nacionalidade, tendo surgido com a catequese das tribos indígenas feita pelos missionários da recém-fundada Companhia de Jesus".

Sobre a estrutura das peças teatrais do jesuíta, é-nos dito o seguinte:

[...] o Auto de Anchieta se inspirara, em sua contextura, dos costumes indígenas; e em sua prosódia e métrica, do estilo de Gil Vicente. Pois, sempre em suas peças se encontra uma parte central em diálogo, que nas composições maiores se divide em dois atos; em redor dessa parte principal nota-se uma introdução ou ato inicial, e dois atos posteriores, dança e despedida, em música e canto. [...] a parte central contém a ação dramática através do diálogo. As outras partes, inicial e finais, são líricas e menores em geral. (CARDOSO S.J., 1977, p. 8)

No Brasil, esse teatro tem sua expansão a partir de 1567 quando José de Anchieta faz apresentar em Piratininga (hoje, São Paulo) o "Auto da pregação universal". Nosso dramaturgo veio para ensinar, mas na verdade teve que aprender, escutar, aprender a língua daquele país, compreender as coisas daquele lugar, etc. Vejamos o que nos conta Hernandes (2008, p. 11-12) sobre o que representa, de forma geral, o teatro anchietano:

[...] o teatro de Anchieta é um acontecimento histórico; seja representação/encenação pedagógica e, portanto, aula de catequese, ele tem enredo, argumento, assunto próprio para um público específico, e é, assim, uma forma de representação cênica situada no tempo: para aproximar-se dele, é preciso considerá-lo na ordem dos acontecimentos e dos efeitos.

O “Auto de São Lourenço" (1587), escrito na maior parte em espanhol e tupi-guarani, trata do martírio de São Lourenço em cinco atos com 1493 versos, com a presença de anjos e demônios. $\mathrm{Na}$ obra, o jesuíta trabalha com a alegoria para disseminar entre os indígenas conceitos cristãos 
como a caridade e a confiança em Deus. Na história, três demônios querem levar os índios para o pecado, porém os santos São Lourenço e São Sebastião os impede. O pe. Armando Cardoso S.J. (1977, p. 16) resume: "no diálogo, em que se desenvolve a ação principal, o enredo ordinário, simples e ingênuo, é a luta dos espíritos do mal contra o anjo da aldeia e os santos protetores, com a vitória destes".

Essa peça se direciona exclusivamente ao público indígena. Os personagens em destaque são os demônios Guaixará e Aimbiré ${ }^{9}$, conhecidos como chefes tamoios que lutaram ao lado dos franceses contra portugueses e jesuítas; outros personagens de destaque são Décio e Valeriano, imperadores romanos dos primeiros séculos ${ }^{10}$.

O Auto tem início já em língua espanhola. O primeiro ato é especial por trazer a cena do martírio de São Lourenço, quando o leitor/ouvinte/expectador vai conhecer a forma como foi martirizado o santo, sendo posto sobre grelhas para assar. Entende-se que esse ato foi cantado, já que, como dissemos acima, Anchieta verteu uma cantiga profana ao divino, que resultou nas quadras abaixo:

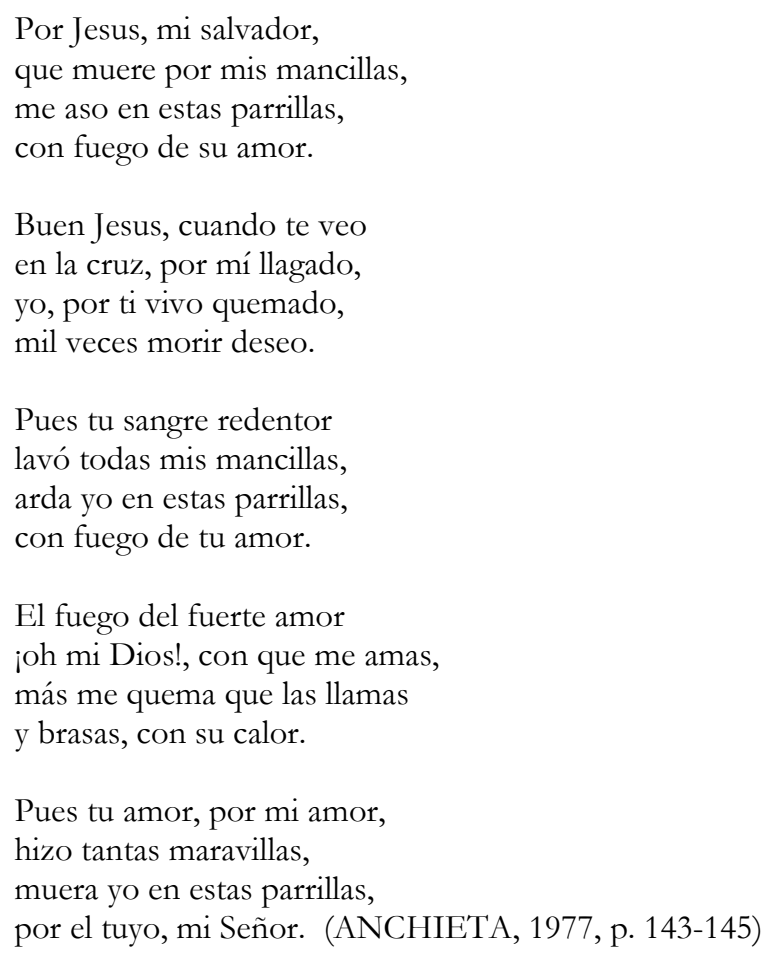

Já na primeira quadra podemos encontrar alguma relação com o ideal antropofágico, tomado do rito canibal, pois a imagem construída pela voz poética é a de um homem assando nas grelhas de um fogo; esse fogo pode traduzir a imagem do rito canibal dos indígenas quando assavam seus

\footnotetext{
${ }^{8}$ Mártires dos primeiros séculos, um foi morto a flechadas e outro assado na fogueira.

9 Segundo informações dadas pelo Pe. Armando Cardoso S.J., os demônios que aparecem nessa peça têm estas características: "Guaixará era índio de Cabo Frio e fora derrotado uma primeira vez, no ataque das duzentas canoas contra a cidade incipiente junto ao Morro do Cão (julho de 1565). [...] Aimbiré é descrito pelo próprio Anchieta na carta de Iperuí, como homem alto, seco, de catadura triste e carregada, que procurou matá-lo quando refém das pazes (a. 1563)" (CARDOSO S.J., 1977, p. 71).

${ }^{10} \mathrm{Na}$ análise da peça feita pelo Pe. Armando Cardoso S.J., ele explica sobre a presença desses personagens: “Os dados históricos que ocorrem sobre personagens, como os imperadores Décio e Valeriano, são tirados da Legenda Áurea, sem valor crítico, que aliás não se deve buscar e exigir em dramas. Segundo a Legenda, foi no tempo de Valeriano, censor do imperador Décio, que foi martirizado S. Lourenço diácono romano de Xisto II, cerca do a. 258 D.C. Depois de atado aos grilhões de ferro, foi açoitado e esfolado e por último posto sobre grelhas em brasa. S. Sebastião é colocado ao seu lado, por ser padroeiro do Rio de Janeiro; foi asseteado no tempo de Diocleciano, cerca do ano 286" (CARDOSO S.J., 1977, p. 142).
} 
inimigos no moquém. O fogo será, nessa peça, um elemento muito presente. Para o pe. Armando Cardoso S.J., com olhar mais voltado para o religioso, ele assim analisa esses versos: "o assunto se funda todo numa ideia de misticismo lírico sublime: o fogo do amor de Jesus para com Lourenço e deste para com Jesus era mais intenso que o fogo material que consumia o corpo do mártir" (CARDOSO S.J., 1977, p. 70). Precisamos, nesse ínterim, explicar que a cena descrita do martírio de São Lourenço como primeiro ato da peça de Anchieta não descreve um ritual antropofágico em que seu corpo seria devorado por seus algozes. No entanto, essa mesma cena nos remete ao ritual canibalesco dos indígenas que matavam seus inimigos, assavam-no em um moquém e depois era consumido por toda a tribo. As duas cenas se assemelham; há, em certa medida, um ato de devoração ${ }^{11}$. A consumação do corpo do mártir era uma espécie de devoração também. É interessante notar que em toda a peça há remissão ao ato de assar, de consumir via fogo.

Já no segundo ato, a língua muda do espanhol para o tupi-guarani ${ }^{12}$, quando surgem três diabos: Guaixará, Aimbirê e Saravaia, representantes da soberba, da astúcia e da traição, respectivamente. Essa mudança de língua vai endossando a mescla linguística presente nessa peça. A primeira fala é de Guaixará, um diabo com nome indígena e falando a língua nativa. Todos os personagens deste ato dialogam na língua tupi, inclusive os mártires São Lourenço e São Sebastião.

Guaixará se apresenta e diz qual fim terá a ação dele e de seus ajudantes naquela aldeia:

\author{
Xe moajú marangatú, \\ xe moyrõetekatuábo \\ aipó tekó pysasú. \\ Abá serã oguerú, \\ xe retáma momoxyábo? \\ Xe añó \\ ko tába pupé aikó \\ serekoáramo uitekóbo, \\ xe rekó rupi imoingóbo. \\ Kué suí asó mamó \\ amó tába rapekóbo. \\ Abá, será, xe jabé? \\ Ixé serobiaripyra, \\ xe añangusú mixyra, \\ Guaixará serímbae, \\ kuépe imoerapoanimbyra.
}

\author{
Oikobé \\ xe pytybõanameté, \\ xe pyri marã tekoára, \\ xe yrúnamo okáibae: \\ tubixakatú Aimbiré, \\ apiába moangaipapára. \\ Tradução: \\ Molesta-me a boa gente, \\ fazendo-me crua guerra; \\ o povo está diferente: \\ quem o mudou de repente, \\ para danar minha terra?
}

\footnotetext{
${ }^{11}$ Nos referimos, especificamente, a algumas tribos que praticavam o ritual canibalesco, como os tupinambás (Cf. LÉRY, 2007).

12 Os trechos em tupi-guarani foram traduzidos pelo pe. Armando Cardoso S.J. (1977) que organizou a obra teatral de José de Anchieta.
} 


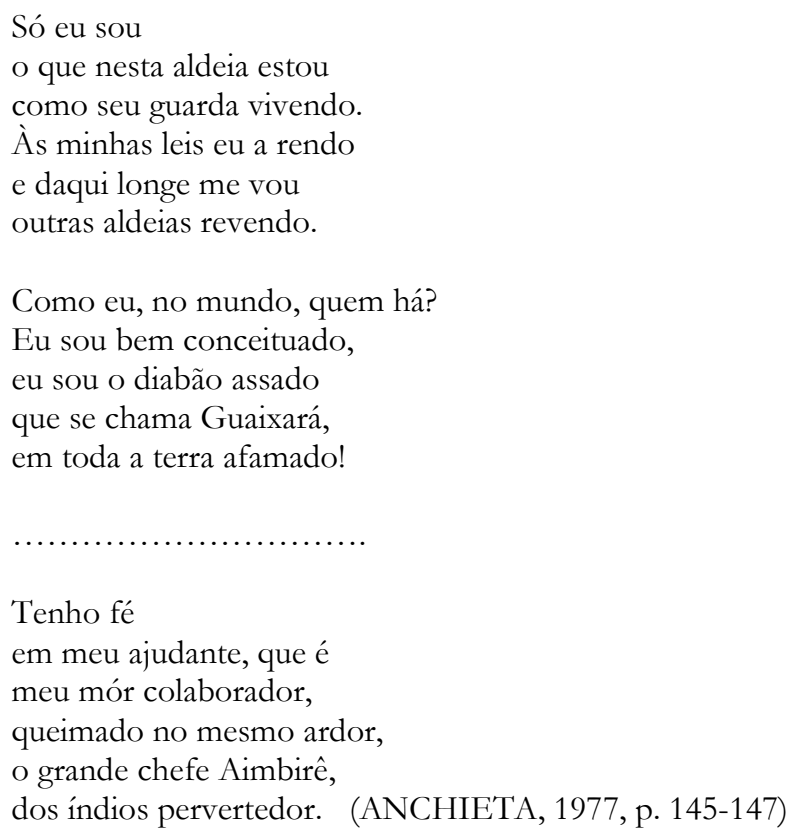

$\mathrm{O}$ ato segue com um diálogo entre os demônios querendo destruir a aldeia com pecados. No entanto, surgem as figuras dos mártires São Lourenço e São Sebastião na presença de um Anjo da Guarda que resistirão aos demônios, livrando toda a aldeia daquela influência maléfica (AZEVEDO FILHO, 1966). Quando os protetores da aldeia são avistados pelos demônios, temos o seguinte diálogo:

Aimbiré: Ke! Abá rekóu añé xe renopuapuáma!

Kái! Rore kae piã?

Saravaia: Aé. Bastião abé.

Aimbiré: Aépe, ke, amboaé?

Saravaia: Karaibebé será

ko tába raroaneté.

Aimbiré: Xe reytyk koríne, mã! Jabaeté sepiáka ixébo...

Guaixará: Aáni xo! Nde piatã! Ejorí! Tixepeñã, imosykyjekyjébo.

Jamonguá moxy ruúba, ixupé jajemoytyámo.

Aimbiré: Ke! Túri jandé nupámo! Aryryi, opá xe úba jesyi, ojemoatámo...

Tradução:

Aimbiré: Olha lá esse sujeito que me está ameaçando!

Ai! o Lourenço queimado?

Saravaia: Sim, ele! e Bastião também.

Aimbiré: E esse outro que está ao lado?

Saravaia: Será o Anjo encarregado que esta aldeia em guarda tem?

Aimbiré: Ai! eles me esmagarão! 
É-me terrível mirá-los...

Guaixará: Sê forte, não fujas, não!

Vem, ataquemos então

para assim amedrontá-los!

Das más flechas escapar! pois nos mostram destruídos.

Aimbiré: Olha, vem-nos açoitar:

meus músculos vão ficar

de tremor endurecidos. (ANCHIETA, 1977, p. 153-154)

Após isso, vale destacar o diálogo empreendido entre os demônios e os mártires, revelando uma tensão entre as forças antagônicas. Nesse diálogo, os mártires questionam a razão pela qual os demônios querem destruir aquela aldeia e eles respondem informando-lhes que aqueles índios são pecadores e nada tem com Deus. Na verdade, ocorre aqui, à luz da catequese, um processo de aculturação. Anchieta objetiva incutir na mente dos seus expectadores que as ações praticadas são consideradas pecados para a Igreja Católica, como o canibalismo, a beberagem do cauim, a mancebia, o fumo, o adultério, as guerras com outras tribos (Cf. AZEVEDO FILHO, 1966, p. 227). Por outro lado, sob olhar estético, o auto vai construindo um conjunto linguístico-cultural bastante coeso e firme no sentido da evocação dos vocábulos indígenas amalgamados às questões litúrgicas católicas. Aprendemos sobre os costumes dos índios, além de também observar o pensamento da Igreja Católica sobre determinados comportamentos dos primeiros habitantes do Brasil. O trecho seguinte é um extrato dessa parte em que dialogam santos e demônios, cada um argumentando sobre o fato de serem donos daquela aldeia:

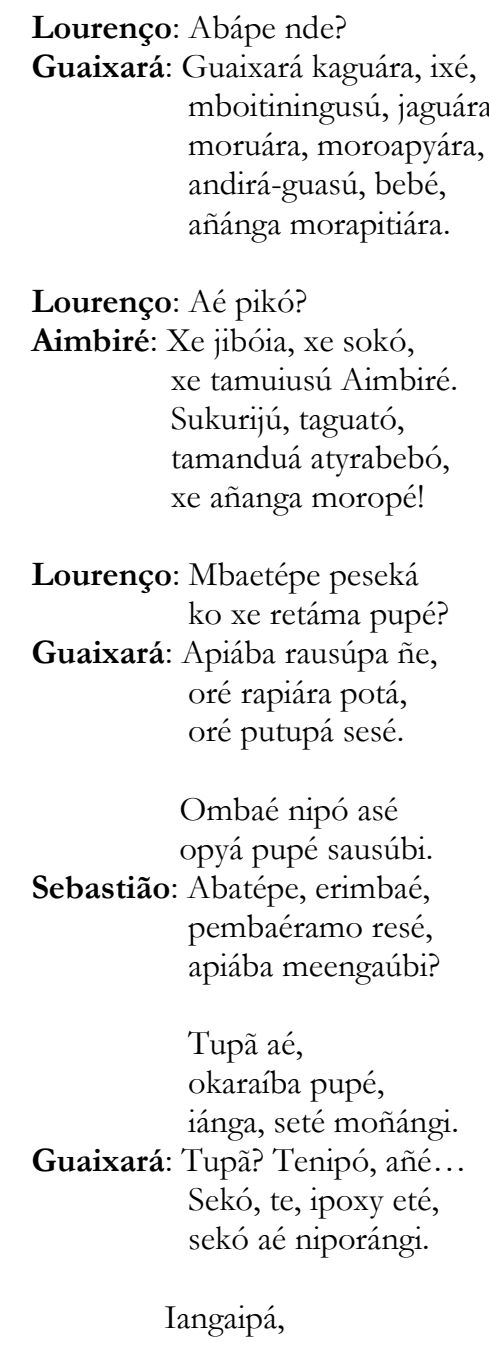


Tupã osausupeá, sesé ojerobiá bebúia.

Aimbiré: Igasápe kaui tujá, aeré iamomotá, ojojá guaibi rekúia...

Imboapy abá kujabá ánga e seminotára. moraséia rerobiára, ipyá jaiporaká, momoetéi omoñangára...

Tradução:

Lourenço: Quem és tu?

Guaixará: Guaixará, o cauçu, sou o grande boicininga, o jaguar da caatinga, eu sou o andirá-guaçu, canibal, demo que vinga.

E ele, é?

Aimbiré: O grão tamoio Aimbiré, sou jibóia, sou socó, sucuriu taguató, demônio-luz, mas sem fé, tamanduá atirabebó!

Lourenço: Aqui, na minha mansão, que buscais por essa via?

Guaixará: Amamos a indiaria! queremos-lhes a sujeição, é toda a nossa porfia.

Ama-se sinceramente

o que é próprio de verdade...

Sebastião: Quem nalgum tempo ou idade vos entregou essa gente para vossa propriedade?

Deus Senhor, com santidade e amor, alma e corpo lhes formou.

Guaixará: Deus? talvez... mas deformou seu viver de mau teor sua alma que não se ornou

Uns sandeus! repelem o amor de Deus e se orgulham pela taba.

Aimbiré: Regorgita a igaçaba: as velhas tentam os seus com cauim que não acaba.

A grande cabaça tolhe a liberdade da mente; em meio da dança quente, nosso carinho os recolhe, desprezando o onipotente. (ANCHIETA, 1977, p. 154-155) 
Ao final desse ato, os demônios são, enfim, presos pelos mártires com a ajuda do Anjo da Guarda da aldeia. Com o surgimento desse outro personagem, fica evidente mais ainda o processo de catequização, porque a figura do Anjo da Guarda representa não somente uma proteção para a aldeia, mas também para cada um daqueles índios, a quem devem recorrer em momento de angústia e desespero, isto é, quando se sentirem acuados pelo "pecado". Vejamos:

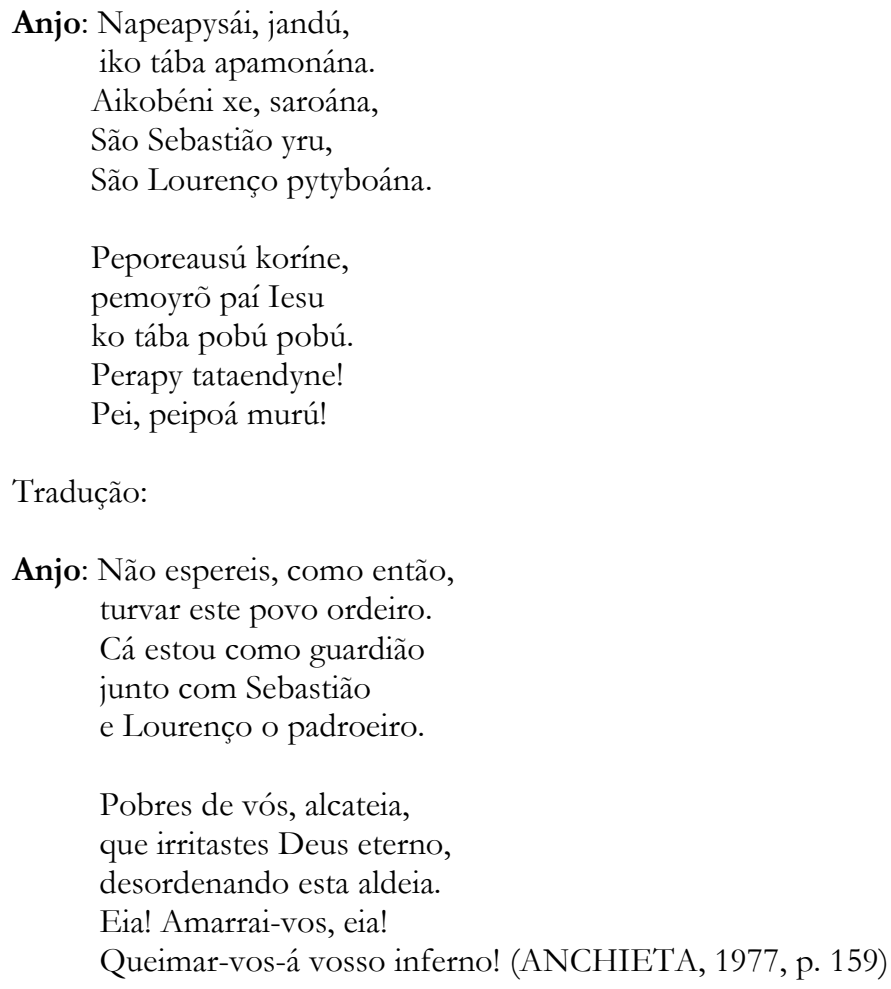

Anjo: Não espereis, como então, turvar este povo ordeiro. Cá estou como guardião junto com Sebastião e Lourenço o padroeiro.

Pobres de vós, alcateia, que irritastes Deus eterno, desordenando esta aldeia. Eia! Amarrai-vos, eia! Queimar-vos-á vosso inferno! (ANCHIETA, 1977, p. 159)

No terceiro ato, surgem outros personagens, Décio e Valeriano, ambos associados ao martírio de São Lourenço. Mais uma vez, há uma mudança linguística; a língua usada agora será o espanhol. Instaura-se um verdadeiro caos linguístico: primeiro espanhol, depois tupi e, em seguida, espanhol e tupi. Isso é bem característico do movimento barroco, dada à sua matéria multifacetada e díspares. Segundo Décio de Almeida Prado (1993, p. 24), o teatro anchietano revela um caos, realizado entre instâncias antagônicas:

Esse verdadeiro caos histórico, ou a-histórico, vai do infinitamente grande ao infinitamente pequeno, do divino ao humano, do material ao imaterial, do passado remoto ao presente imediato, do local ao universal, formando um bloco cultural complexo a que unicamente os padres da Companhia de Jesus (e talvez nem todos) estavam em condições de ter acesso.

Nesse ato, o Anjo pede para que os demônios afoguem os imperadores Décio e Valeriano como castigo por terem martirizado São Lourenço, que segundo Leodegário Azevedo Filho (1966, p. 227-228), trata-se de um naturalismo de aspecto barroco: "Assume, então, aspecto de naturalismo barroco a cena em que os demônios planejam a destruição dos imperadores, aproximando-se o clímax principal do Auto, após uma série de involuções".

As falas do Anjo e dos demônios ocorrem em tupi-guarani, enquanto que as dos imperadores ocorrem em língua espanhola:

Anjo: Nei, taujé iajubyka! Tosepiáki be umé koarasy! Nei, taujé nde ratá pupé seytyka! 
Peñeiñáng pabe sesé!

Aimberé: Nei! Tasó

aipó ñeénga mopó, xe bojá reiñãngetábo. Sarauái, jorí ekaguábo, aeré korí jasó tubixabá akánga kábo.

Tradução:

Anjo: Eia, depressa, a afogá-los! Que não vejam mais o dia! Eia, depressa, a atirá-los ao fogo de vossos valos! Reuni a companhia!

Aimbiré: Pronto! Irei executar vossa lei, reunir a minha laia. Vem beber, ó Saravaia! Vamos, hoje fendei as cabeças desta arraia! (ANCHIETA, 1977, p. 166)

Décio e Valeriano entram em cena falando em espanhol:

Décio: Amigo Valeriano, es cumplido mi deseo, pues por arte ni rodeo, pudo escapar de mi mano el siervo del Galileo.

Ni Pompeyo, ni Catón, ni César, ni el Africano, ningún griego ni troyano pudieron dar conclusión a hecho tan soberano.

Valeriano: El remate, gran señor, de esta tan grande hazaña, fué más que vencer España. Nunca rey, ni emperador hizo cosa tan extraña.

Mas, señor, ¿quién es aquel que allí veo tan armado con espadas y cordel, y con gente de tropel, de que viene acompañado?

Décio: Es nuestro gran Dios y amigo

Júpiter, sumo Señor, que recibió gran sabor con el horrendo castigo y muerte de este traidor.

Y quiere, por regraciar las penas de este profano, nuestro imperio acrescentar, con su poderosa mano, por la tierra y por la mar. 


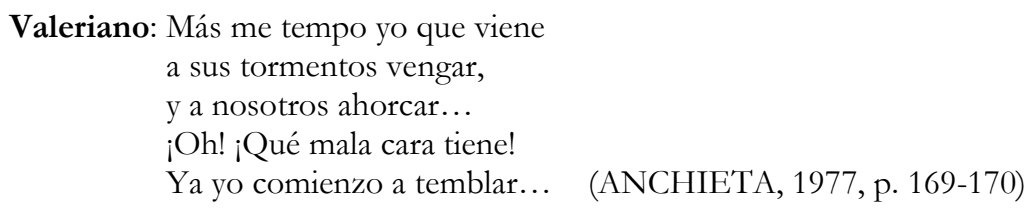

A cena segue e os diabos começam a conversar com os imperadores. Temos nesse ato, um encontro entre épocas muito distantes, são índios do século XVI em diálogo com imperadores da época romana. A esse respeito, o pe. Armando Cardoso S.J. (1977, p. 73) faz a seguinte consideração:

Podia parecer anacronismo dialogarem demônios índios do séc. XVI com os imperadores Décio e Valeriano, algozes do mártir no séc. III, ora em castelhano ora em tupi. Mas todos vemos que os demônios, embora se chamem, nesse teatro especial, com nomes de chefes inimigos, não deixam de ser diabos que existiram desde a criação do mundo.

Para o crítico jesuíta, essa cena não é do mundo terrenal, mas do espiritual, “onde os tempos se aproximam e se falam todas as línguas" (CARDOSO S.J., 1977, p. 73). É uma visão estritamente religiosa. Para nós, a importância maior é o caudal linguístico-cultural que vai sendo construído cena a cena, por isso, antropofágico.

Quando começa o discurso do diabo Aimbiré, sua fala é posta em tupi, no entanto, na quadra seguinte, ele já fala espanhol:

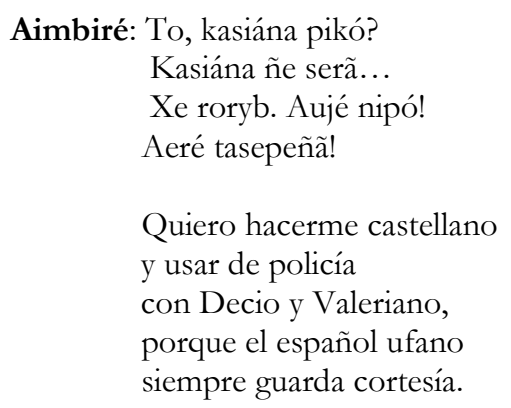

Tradução:

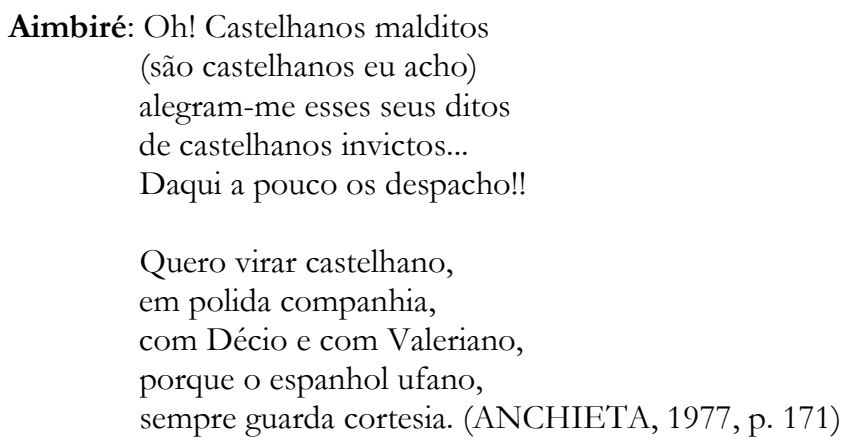

Em seguida, ocorre o contrário, Valeriano, o imperador castelhano, fala em tupi com o demônio Aimbiré, e este mistura as duas línguas em uma só fala. Observe-se que cada um desses exemplos vai justificando o processo de devoração linguística empreendido por José de Anchieta para produzir essa peça:

Valeriano: Xe, akái!

Aimbiré: ¿Vinisteis del Paraguay, que habláis en carijó?

Todas las lenguas sé yo. 
sepeñã, Sarauái!

Ko nde momboitába, ko!

Valeriano: Aujé, xe juká jepé!

Nasetái xe angaipába...

Ejá, te, xe rubixába!

Saravaia: Aã! Xe potába nde!

Nde, xe rembiapotasába!

Tradução:

Valeriano: Xe, akái!

Aimbiré: Viestes do Paraguai, que falais em guarani?

Todas as línguas aprendi...

Avança tu, Saravaia,

aqui teus golpes, aqui!

Valeriano: Oh, basta! que me estraçalhas: eu não tenho muitas falhas...

Prende antes o meu chefão!

Saravaia: Não! És tu o meu quinhão,

és presa que bem me calhas! (ANCHIETA, 1977, p. 172)

A língua espanhola era nobre naquela época. A classe dominante da Península era bilíngue. Por essa razão, o diabo Aimbirê fala em espanhol na peça. "Não se pense, todavia, que esse surpreendente intercâmbio de idiomas seja involuntário ou produto de desatenção" (PRADO, 1993, p. 28).

Quando chegamos ao quarto ato, surge novamente o personagem do Anjo que vai dialogar com dois personagens simbólicos, o Temor e o Amor de Deus. A cena é a do sepultamento do corpo de São Lourenço. Ocorre outra mistura linguística: o Anjo abre o ato falando em português e depois os outros personagens falam em espanhol:

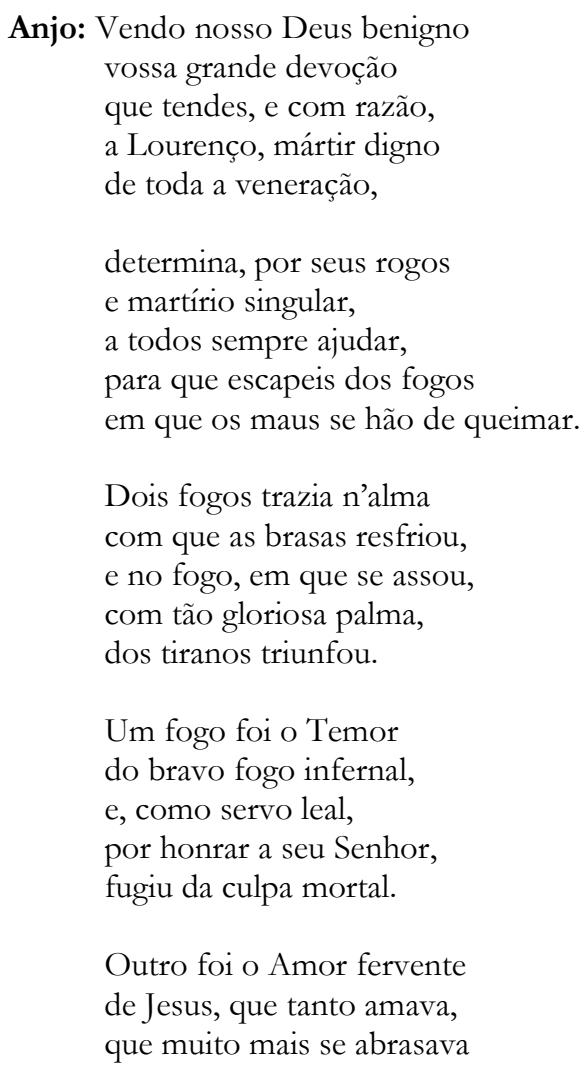


com esse fervor ardente

que co'o fogo, em que se assava.

(ANCHIETA, 1977, p. 179).

Em seguida, falam o Temor e o Amor. Na interpretação religiosa do pe. Armando Cardoso S.J. (1977, p. 75), “Os sermões do Temor e Amor de Deus são duas composições líricas de alto valor literário. No auto eles têm por finalidade fixar, através de suas voltas inspiradas, o fruto espiritual de toda a peça, um pouco como os coros gregos que levavam à reflexão sobre a vida humana e seu destino".

O Temor dá seu recado:

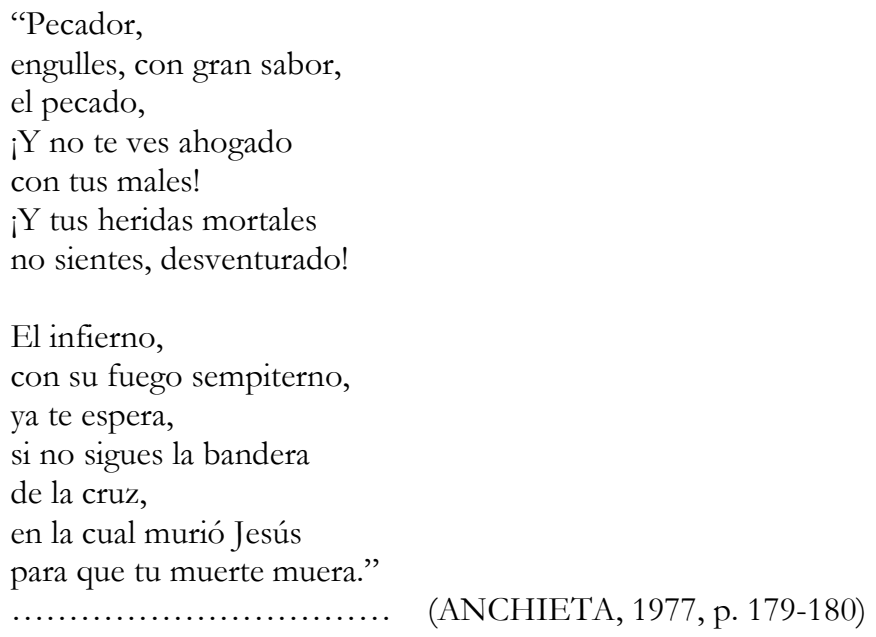

Em seguida, vem o recado do Amor de Deus:

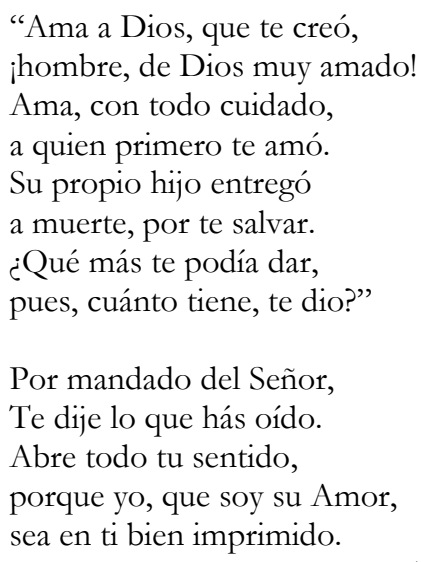

(ANCHIETA, 1977, p. 184)

A peça termina no $5^{\circ}$ ato com um baile, uma festa cantada em tupi-guarani. É uma verdadeira festa da palavra, festa das línguas, na qual o ideal de devoração está posto na mesa. O banquete linguístico oferecido a nós por Anchieta é um dos mais maravilhosos. O banquete barroco dado aos indígenas nas terras coloniais está carregado de signos culturais, pois a língua é o substrato da cultura de cada povo. Ao mudar a língua, mudam os ideais, os pensamentos, as visões, os sotaques, as vozes e, embora estejam sozinhas na boca dos personagens, ao final, estão unidas ao complexo antropofágico construído pelo jesuíta aqui pesquisado.

$\mathrm{Na}$ verdade, sabemos que os jesuítas queriam substituir uma cultura por outra, mas há um sincretismo, como pudemos observar nos exemplos acima, um sincretismo linguístico; as culturas que foram evocadas caminham de mãos dadas, não estão separadas, mesmo com a separação da 
língua por atos e por personagens. Portanto, a realidade literária já é brasileira e começa pela mão do barroco.

Leodegário Azevedo Filho (1966, p. 232), nos ajuda a concluir:

O teatro de Anchieta é assim. Reflete, em sua entrega apaixonada à realidade brasileira, traços naturalísticos próprios do Barroco, através de seu ilusionismo pictórico e do patético religioso. Nele se reflete, vivo, o tremor ideológico e místico da Contrarreforma, buscando estremecidamente a evidência do sobrenatural, numa espécie de estética da salvação do gentio.

A procissão final da peça feita por meninos que dançam e cantam em tupi é mais um exemplo do processo de devoração antropofágica. Era comum, no teatro medieval, haver uma parte final composta pelo lúdico e, na cultura indígena, também era costume haver festas com danças e cânticos. Anchieta une esses dois universos culturais diferentes, que, ao se unirem, provocam uma tensão, uma tensão barroca, resultando, portanto, na cultura brasileira, "de um lado se mantém o espírito antiterreno da Idade Média, encarnado nos padres da Companhia de Jesus, e, de outro, o que se tem é o mundo pagão do silvícola" (AZEVEDO FILHO, 1966, p. 57).

\section{CONSIDERAÇÕES FINAIS}

O estudo da peça teatral "Auto de São Lourenço" revelou-nos, claramente, uma possível conexão entre o barroco anchietano (ainda em formação aqui no Brasil) e a antropofagia oswaldiana, ou seja, estabelecendo uma ponte entre uma obra quinhentista e uma teoria moderna, o que corrobora com a concepção de que a literatura não pode ser vista somente sob barreiras historicistas. E isso não é anacrônico, mas sincrônico. Tal conexão se deu, essencialmente, pela confluência linguística presente nessa peça, na qual Anchieta faz contracenar anjos, demônios, santos e imperadores, personagens que dialogam em línguas diferentes a depender da cena e do interlocutor.

Em todo o auto, vemos sendo construído o ideal barroco-antropofágico de devoração da palavra, cujo cerne está no trabalho meticuloso exercido por Anchieta nas escolhas das palavras, das línguas e dos personagens. A produção da peça com fins pedagógicos suplanta seu objetivo quando insere os elementos paradoxais das culturas que estão ali representadas por cada personagem, revelando-nos a formação de uma nova cultura, a brasileira. Nas linhas desse auto, enxergamos esse processo formativo, porque tanto na peça quanto no público expectador está representada toda a diversidade que compõe o Brasil. Somos resultado desse processo de amalgamação linguístico-cultural que está presente na obra do jesuíta, que também é fruto de outras amalgamações. Anchieta trouxe para as terras brasileiras a literatura e a cultura de matriz medieval que fizeram parte de sua educação humanista e aqui empreendeu, por meio da antropofagia, a amalgamação com a cultura autóctone. Seu texto não é mais português nem medieval; é agora um terceiro elemento, fruto da união entre esses dois ambientes tão díspares, europeu e americano, fazendo-se uno, portanto, barroco.

O teatro anchietano nos apresenta culturas e mundos diversos. Une o Velho e o Novo, transformando-os em Um. Essa união é possível porque é no teatro que ocorre a transmutação das culturas e o encontro das línguas. Anchieta traz os louvores da Espanha para os indígenas da América. O signo linguístico espanhol encontra o homem silvícola em seu primitivismo e se absorve do signo verbal indígena. Dessa maneira, não se pode dizer que Anchieta é um poeta de São Paulo, da Bahia ou do Rio de Janeiro, nem só brasileiro ou espanhol; é, na verdade, universal. Sua obra não admite o regionalismo, o particular. Anchieta é muito mais que um jesuíta, é um poeta:

En el jesuita se produce la insólita circunstancia de que la forma del "hombre" ha silenciado al "literato" el tiempo suficiente para que la memoria histórica sólo asociara a 
su nombre a la identidad del "evangelizador" y del "beato" y no a la del "poeta" o a la del "dramaturgo". [...] el Padre Anchieta también formula con "transcontinentalidad" el viejo debate entre la insularidad o la universalidad. (DÍAZ, 1998, p. 11-12, grifos do autor).

Com sua escrita polilíngue, Anchieta é "muitos", reunindo o mundo do qual provém a essência do seu teatro - o homem. Anchieta foi um homem, um religioso, um poeta, um dramaturgo, um santo, que, através de sua lírica, conseguiu instituir toda uma nova vida cultural/literária/religiosa para a gente brasileira. Muito mais que isso, trouxe para o solo brasileiro as marcas do teatro barroco tão intimamente interconectado por seus versos, observados por meio da antropofagia cultural. Os temas recorrentes no teatro anchietano comungam com os mesmos temas trabalhados pelos poetas barrocos no Velho Mundo, significando que o Novo Mundo, no nosso caso, Brasil, começava pela via direita da literatura.

\section{REFERÊNCIAS}

ANCHIETA, S.J., Joseph de. Teatro de Anchieta. São Paulo: Edições Loyola, 1977. - Arte de gramática da língua mais usada na costa do Brasil. São Paulo: Edições Loyola, 1990.

ANDRADE, Oswald de. Do Pau-Brasil à Antropofagia e às Utopias. Manifestos, teses de concursos e ensaios. 2. ed. Rio de Janeiro: Civilização Brasileira, 1978. (Obras Completas VI)

AZEVEDO FILHO, Leodegário Amarante de. Anchieta, a Idade Média e o Barroco. Rio de Janeiro: Gernasa, 1966.

AZZI, Riolando. A cristandade colonial: um projeto autoritário. São Paulo: Paulinas, 1987.

BITARÃES NETTO, Adriano. Antropofagia oswaldiana: um receituário estético e científico. São Paulo: Annablume, 2004.

CARDOSO, S.J., Pe. Armando. Introdução histórico-literária. In: ANCHIETA, S.J., Joseph de. Teatro de Anchieta. São Paulo: Edições Loyola, 1977. p. 5-111.

CAXA, Quirício; RODRIGUES, Pero. Primeiras biografias de José de Anchieta. Introdução e Notas do Pe. Hélio Abranches Viotti, S.J. São Paulo: Loyola, 1988.

DELEUZE, Gilles. A dobra: Leibniz e o barroco. Trad. Luiz B. L. Orlandi. 2. ed. Campinas: Papirus, 2000.

DÍAZ, Carlos Britto. Poesías líricas castellanas. [S.l.]: Instituto de Estudos Canarios, 1998.

FAUSTINO, Mário. De Anchieta aos concretos. Org. Maria Eugênia Boaventura. São Paulo: Companhia das Letras, 2003.

GELADO, Viana. Poéticas da transgressão: vanguarda e cultura popular nos anos 20 na América Latina. Rio de Janeiro: 7letras; São Carlos, SP: EdUFSCar, 2006.

HELENA, Lúcia. Uma literatura antropofágica. Rio de Janeiro: Cátedra; Brasília: INL, 1981. 
HERNANDES, Paulo Romualdo. O teatro de José de Anchieta: arte e pedagogia no Brasil Colônia. Campinas, SP: Editora Alínea, 2008.

HORNAERT, Eduardo et al. História da Igreja no Brasil: ensaios de interpretação a partir do povo Primeira época - período colonial. 5. ed. Petrópolis/RJ: Vozes, 2008.

LACOUTURE, Jean. Os jesuitas: 1. Os conquistadores. Trad. Ana Maria Capovilla. Porto Alegre: L\&PM, 1994.

LERY, Jean de. Viagem à terra do Brasil. Trad. Sérgio Milliet. Belo Horizonte: Ed. Itatiaia, 2007.

LEZAMA LIMA, José. La expresión americana. México: FCE, 2005.

PRADO, Décio de Almeida. Teatro de Anchieta a Alencar. São Paulo: Perspectiva, 1993.

SARDUY, Severo. Barroco. Trad. Maria de Lurdes e José Manuel de Vasconcelos. Lisboa: Vega Universidade, 1988.

VASCONCELOS, Simão de. Vida do Venerável Padre José de Anchieta. Rio de Janeiro: Imprensa Nacional, 1943.

Submetido em 23/09/2019

Aceito em 19/11/2019

Publicado em 17/01/2020 